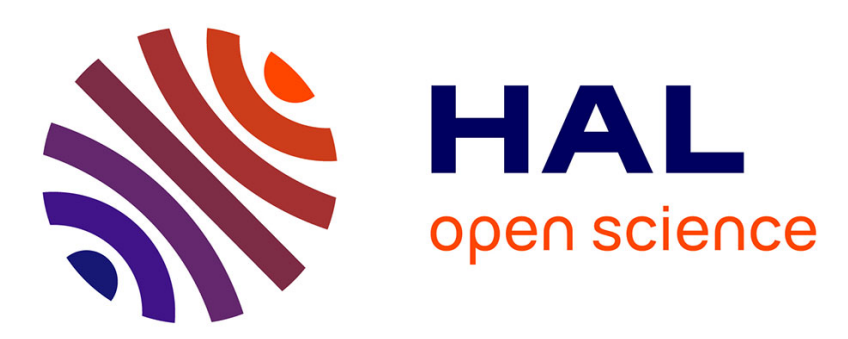

\title{
Molecular identification of bacteria associated with canine periodontal disease
}

\author{
Marcello P. Riggio, Alan Lennon, David J. Taylor, David Bennett
}

\section{To cite this version:}

Marcello P. Riggio, Alan Lennon, David J. Taylor, David Bennett. Molecular identification of bacteria associated with canine periodontal disease. Veterinary Microbiology, 2011, 150 (3-4), pp.394. 10.1016/j.vetmic.2011.03.001 . hal-00696631

\section{HAL Id: hal-00696631 \\ https://hal.science/hal-00696631}

Submitted on 13 May 2012

HAL is a multi-disciplinary open access archive for the deposit and dissemination of scientific research documents, whether they are published or not. The documents may come from teaching and research institutions in France or abroad, or from public or private research centers.
L'archive ouverte pluridisciplinaire HAL, est destinée au dépôt et à la diffusion de documents scientifiques de niveau recherche, publiés ou non, émanant des établissements d'enseignement et de recherche français ou étrangers, des laboratoires publics ou privés. 


\section{Accepted Manuscript}

Title: Molecular identification of bacteria associated with canine periodontal disease

Authors: Marcello P. Riggio, Alan Lennon, David J. Taylor, David Bennett

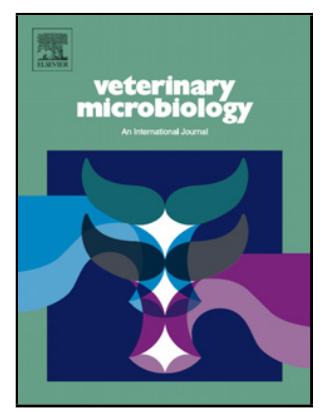

PII: S0378-1135(11)00139-8

DOI: doi:10.1016/j.vetmic.2011.03.001

Reference: VETMIC 5224

To appear in: VETMIC

Received date: 3-11-2010

Revised date: 28-2-2011

Accepted date: 2-3-2011

Please cite this article as: Riggio, M.P., Lennon, A., Taylor, D.J., Bennett, D., Molecular identification of bacteria associated with canine periodontal disease, Veterinary Microbiology (2010), doi:10.1016/j.vetmic.2011.03.001

This is a PDF file of an unedited manuscript that has been accepted for publication. As a service to our customers we are providing this early version of the manuscript. The manuscript will undergo copyediting, typesetting, and review of the resulting proof before it is published in its final form. Please note that during the production process errors may be discovered which could affect the content, and all legal disclaimers that apply to the journal pertain. 
1 Molecular identification of bacteria associated with canine periodontal disease

2

3 Marcello P. Riggio ${ }^{1 *}$, Alan Lennon ${ }^{1}$, David J. Taylor ${ }^{1}$, David Bennett ${ }^{1}$

4

$5 \quad{ }^{1}$ Infection \& Immunity Research Group, Dental School, University of Glasgow, Glasgow, UK

$6 \quad{ }^{2}$ School of Veterinary Medicine, University of Glasgow, Glasgow, UK

$8{ }^{*}$ Corresponding author: Marcello P. Riggio, Infection \& Immunity Research Group, Level 9,

9 Glasgow Dental Hospital \& School, 378 Sauchiehall Street, Glasgow G2 3JZ, UK. Phone: +44

10141 2119742; Fax: +44 141 3531593; E-mail: Marcello.Riggio@glasgow.ac.uk

11

12

13

14

15

16

17

18

19

20

21 


\section{Abstract}

Periodontal disease is one of the most common diseases of adult dogs, with up to $80 \%$ of animals affected. The aetiology of the disease is poorly studied, although bacteria are known to play a major role. The purpose of this study was to identify the bacteria associated with canine gingivitis and periodontitis and to compare this with the normal oral flora. Swabs were obtained from the gingival margin of three dogs with gingivitis and three orally healthy controls, and subgingival plaque was collected from three dogs with periodontitis. Samples were subjected to routine bacterial culture. The prevalent species identified in the normal, gingivitis and periodontitis groups were uncultured bacterium (12.5\% of isolates), Bacteroides heparinolyticus / Pasteurella dagmatis (10.0\%) and Actinomyces canis (19.4\%), respectively. Bacteria were also identified using culture-independent methods (16S rRNA gene sequencing) and the predominant species identified were Pseudomonas sp. (30.9\% of clones analysed), Porphyromonas cangingivalis (16.1\%) and Desulfomicrobium orale (12.0\%) in the normal, gingivitis and periodontitis groups, respectively. Uncultured species accounted for $13.2 \%, 2.0 \%$ and $10.5 \%$, and potentially novel species for $38.2 \%, 38.3 \%$ and $35.3 \%$, of clones in the normal, gingivitis and periodontitis groups, respectively. This is the first study to use utilise culture-independent methods for the identification of bacteria associated with this disease. It is concluded that the canine oral flora in health and disease is highly diverse and also contains a high proportion of uncultured and, in particular, potentially novel species.

Keywords: canine periodontal disease / bacteria / microbiological culture / 16S rRNA / polymerase chain reaction 


\section{Introduction}

Periodontal disease (gingivitis and periodontitis) is one of the most common infectious

52 diseases affecting adult dogs, with up to $80 \%$ of animals of all breeds affected (Golden et al.,

53 1982; Harvey \& Emily, 1993; Harvey, 1998). The incidence of the disease increases markedly

54 with advancing years and causes significant oral pain and suffering. Periodontal disease has been

55 described as a multi-factorial infection (Lindhe et al., 1973), and plaque bacteria are known to be

56 an important causative factor. Gingivitis is completely reversible and is recognised by the classic

57 signs of halitosis, bleeding, inflammation, redness and swelling of the gingivae. Periodontitis is

58 irreversible and attacks the deeper structures that support the teeth, permanently damaging the

59 surrounding bone and periodontal ligament and resulting in increased periodontal pocket depth

60 and tooth loss. The aetiology of canine periodontal disease remains unknown, although gram-

61 negative anaerobic bacteria have been implicated in the disease (Hennet \& Harvey, 1991a, b;

62 Boyce et al., 1995).

63 In recent years, the use of culture-independent (bacterial 16S rRNA gene sequencing)

64 methods has supplemented traditional culture-dependent methods to detect bacteria in clinical

65 specimens. 16S rRNA gene sequencing has permitted the identification of bacteria which are

66 uncultivable, fastidious in their growth requirements and even novel, in addition to detecting

67 known cultivable species (Clarridge, 2004; Spratt, 2004). In the current study, the bacteria

68 associated with canine periodontal disease, and with the normal canine oral cavity, were

69 identified using both culture-dependent and culture-independent methods. 


\section{Materials and methods}

\subsection{Sample collection and processing}

Ethical approval for the study was obtained from the Local Research Ethics Committee.

Samples were classified into normal and diseased groups as follows: no gingival inflammation,

no periodontal pockets (normal); gingival inflammation and/or periodontal pockets less than 3

$\mathrm{mm}$ in depth (gingivitis); periodontal pockets at least $4 \mathrm{~mm}$ in depth (periodontitis). Dental plaque was collected using sterile swabs from the gingivae of periodontally healthy dogs (three samples) and animals with gingivitis (three samples). For the periodontitis cases (three samples), subgingival plaque was collected using a sterile curette from the periodontal pocket. Swabs were placed into sterile reduced transport medium and subgingival plaque was immersed into $1 \mathrm{~mL}$ of fastidious anaerobe broth (FAB) and immediately sent for laboratory analysis. Each swab was then immersed into $1 \mathrm{~mL}$ of FAB. All samples were mixed for $30 \mathrm{~s}$ to remove bacteria.

\subsection{Bacterial culture}

Ten-fold serial dilutions (to $10^{-6}$ ) were prepared for each sample and spiral plated onto both

91 Columbia agar containing $7.5 \%$ (v/v) defibrinated horse blood (for aerobic culture) and fastidious

92 anaerobe agar (FAA) (BioConnections, Wetherby, UK) containing 7.5\% (v/v) defibrinated horse

93 blood (for anaerobic culture). Columbia blood agar plates were incubated in $5 \% \mathrm{CO}_{2}$ at $37^{\circ} \mathrm{C}$, 94 and FAA plates were incubated at $37^{\circ} \mathrm{C}$ in an anaerobic chamber with an atmosphere of $85 \% \mathrm{~N}_{2} /$

$9510 \% \mathrm{CO}_{2} / 5 \% \mathrm{H}_{2}$ at $37^{\circ} \mathrm{C}$. Plates were incubated for up to seven days, and up to eight 96 morphologically distinct colonies (visually representing the most abundant colony types) were 
97 then subcultured in order to obtain pure cultures. Bacterial isolates were identified by $16 \mathrm{~S}$ rRNA

98 gene sequencing as described below.

99

100

\subsection{Extraction of DNA from samples}

101

A bacterial DNA extract was prepared from each sample by digestion with 1\% SDS and proteinase $\mathrm{K}(100 \mathrm{ug} / \mathrm{mL})$ at $60^{\circ} \mathrm{C}$ for $1 \mathrm{~h}$, followed by boiling for $10 \mathrm{~min}$. Extraction of DNA from bacterial isolates was carried out using the same method.

Bacterial 16S rRNA genes were amplified by PCR using the universal primers 5'-

110 (Marchesi et al., 1998). PCR reactions were carried out in a total volume of $50 \mu \mathrm{L}$ containing 5

$111 \mu \mathrm{L}$ of the extracted DNA and $45 \mu \mathrm{L}$ of reaction mixture comprising $1 \times$ GoTaq ${ }^{\circledR}$ PCR buffer

112 (Promega, Southampton, UK) 1.25 units of GoTaq ${ }^{\circledR}$ polymerase (Promega), $1.5 \mathrm{mM} \mathrm{MgCl}_{2}, 0.2$

$113 \mathrm{mM}$ dNTPs (New England Biolabs, Hitchin, UK), and each primer at a concentration of $0.2 \mu \mathrm{M}$.

114 The PCR cycling conditions comprised an initial denaturation phase of $5 \mathrm{~min}$ at $95^{\circ} \mathrm{C}$, followed

115 by 35 cycles of denaturation at $95^{\circ} \mathrm{C}$ for $1 \mathrm{~min}$, annealing at $58^{\circ} \mathrm{C}$ for $1 \mathrm{~min}$ and primer extension 116 at $72^{\circ} \mathrm{C}$ for $1.5 \mathrm{~min}$, and finally a primer extension step at $72^{\circ} \mathrm{C}$ for $10 \mathrm{~min}$. 
123 Stringent procedures were adhered to in order to prevent contamination during the PCR

124 process (Riggio et al., 2000). Negative and positive control reactions were included with every 125 batch of samples being analysed. The positive control comprised a standard PCR reaction 126 mixture containing 10 ng of Escherichia coli genomic DNA instead of sample, whereas the 127 negative control contained sterile water instead of sample. PCR products $(10 \mu \mathrm{L})$ were 128 electrophoresed on $2 \%(\mathrm{w} / \mathrm{v})$ agarose gels, stained with ethidium bromide $(0.5 \mu \mathrm{g} / \mathrm{mL})$ and 129 visualised under ultraviolet light.

130

\section{2.6. Cloning of $16 S$ rRNA PCR products}

PCR products were cloned into the $\mathrm{pSC}-\mathrm{A}$-amp/kan plasmid vector using the StrataClone ${ }^{\mathrm{TM}}$

134 PCR Cloning Kit (Stratagene) in accordance with the manufacturer's instructions.

2.7. PCR amplification of $16 S$ rRNA gene inserts

138 Following cloning of the 16S rRNA gene products amplified by PCR for each sample, 139 approximately 50 clones from each library were selected at random. The 16S rRNA gene insert 140 from each clone was amplified by PCR with the primer pair 5'141 CCCTCGAGGTCGACGGTATC-3' (M13SIF) and 5'-CTCTAGAACTAGTGGATCCC- 3' 142 (M13SIR). The M13SIF binding site is located 61 base pairs downstream of the M13 reverse 143 primer-binding site, and the M13SIR binding site is located 57 base pairs upstream of the M13 $144-20$ primer-binding site, in the $\mathrm{pSC}-\mathrm{A}$-amp/kan plasmid vector. 
147 16S rRNA gene inserts amplified by PCR were subjected to restriction enzyme analysis.

148 Approximately $0.5 \mu \mathrm{g}$ of each PCR product was digested in a total volume of $20 \mu \mathrm{L}$ with 2.0 149 units of each of the restriction enzymes RsaI and MnlI (Fermentas Life Sciences, York, UK) at

$15037^{\circ} \mathrm{C}$ for $2 \mathrm{~h}$ and the generated restriction fragments visualised by agarose gel electrophoresis.

151 For each library, clones were initially sorted into groups based upon the $R s a$ I restriction digestion

152 profiles and further discrimination was achieved by digestion of clones with MnlI. Clones with

153 identical 16S rRNA gene restriction profiles for both enzymes were assigned to distinct 154 restriction fragment length polymorphism (RFLP) groups.

The 16S rRNA gene insert of a single representative clone from each RFLP group was sequenced. Sequencing was performed with the SequiTherm EXCELTM II DNA Sequencing Kit

160 (Cambio, Cambridge, UK) and IRD800-labelled 357f sequencing primer (5'161 CTCCTACGGGAGGCAGCAG-3') using the following cycling conditions: (i) initial 162 denaturation at $95^{\circ} \mathrm{C}$ for $30 \mathrm{~s}$; (ii) $10 \mathrm{~s}$ at $95^{\circ} \mathrm{C}, 30 \mathrm{~s}$ at $57^{\circ} \mathrm{C}$ and $30 \mathrm{~s}$ at $70^{\circ} \mathrm{C}$, for 20 cycles and 163 (iii) $10 \mathrm{~s}$ at $95^{\circ} \mathrm{C}$ and $30 \mathrm{~s}$ at $70^{\circ} \mathrm{C}$ for 15 cycles. Formamide loading dye $(6 \mu \mathrm{L})$ was added to 164 each reaction mixture after thermal cycling and $1.5 \mu \mathrm{L}$ of each reaction mixture was run on a LI-

165 COR Gene ReadIR 4200S automated DNA sequencing system 
171 Sequence data were compiled using LI-COR Base ImagIR 4.0 software, converted to FASTA

172 format and compared with bacterial 16S rRNA gene sequences from the EMBL and GenBank 173 sequence databases using the advanced gapped BLAST program, version 2.1 (Altschul et al., 174 1997). The program was run through the National Centre for Biotechnology Information website 175 (http://www.ncbi.nlm.nih.gow/BLAST). Clone sequences with at least 98\% identity with a 176 known sequence from the database were designated the same species as the matching sequence 177 with the highest score. Clone sequences with less than $98 \%$ identity were tentatively classified as 178 putative novel phylotypes.

\subsection{Statistical analysis}

181 To determine whether the observed differences in the microflora between each of the three 182 groups were of statistical significance, a cross-tabulation using Fisher's exact test was performed. 183 A level of statistical significance was indicated by $\mathrm{p}<0.0167$ (Bonferroni correction).

\section{Results}

\subsection{Culture-dependent identification of bacteria}

Bacterial isolates obtained following microbiological culture of samples were identified by 190 16S rRNA gene sequencing, and the results are shown in Table 1. All isolates had identities of at

191 least $98 \%$ with a known database sequence. Of the 32 isolates obtained from the normal samples, 
193 weaveri (three isolates, 9.4\%). Thirty isolates were obtained from the gingivitis samples, of

194 which three (10\%) were identified as Bacteroides heparinolyticus and three (10\%) as Pasteurella

195 dagmatis. For the periodontitis samples, 36 isolates were identified and the predominant species

196 was Actinomyces canis (seven isolates, 19.4\%).

197

\subsection{Culture-independent identification of bacteria}

Following 16S rRNA PCR analysis, all nine samples were shown to be positive for the

presence of bacteria. For the three normal samples, 152 clones were analysed and 83 clones were sequenced. Bacteria with identities of at least $98 \%$ with a known database sequence are grouped according to species in Table 2, with a total of 19 phylotypes being identified. The predominant species was Pseudomonas sp. (30.9\% of clones analysed). Uncultured species (three phylotypes) accounted for $20(13.2 \%)$ of clones analysed. Fifty-eight (38.2\%) of clones analysed (17 phylotypes) represented potentially novel species (Table 3).

In total, 149 clones were analysed and 96 clones were sequenced across the three gingivitis samples. The bacteria identified (24 phylotypes) are grouped according to species in Table 2 . The predominant species was Porphyromonas cangingivalis (16.1\% of clones analysed). Uncultured species (two phylotypes) accounted for $3(2.0 \%)$ of clones analysed. Fifty-seven (38.3\%) of clones analysed (15 phylotypes) represented potentially novel species (Table 3).

213 clones being sequenced. The bacteria identified (20 phylotypes) are grouped according to species

214 in Table 2. The predominant species was Desulfomicrobium orale (12.0\% of clones analysed).

215 Uncultured species (four phylotypes) accounted for 14 (10.5\%) of clones analysed. Forty-seven 216 (35.3\%) of clones analysed (17 phylotypes) represented potentially novel species (Table 3). 


\subsection{Statistical analysis}

218 In order to determine if the differences in the microflora observed in each of the three groups

219 was statistically significant, a three-way comparison between groups using cross-tabulation with

220 a Fisher's exact test was performed for the data presented in Tables 1-3.

221 For bacteria identified by culture-dependent methods (Table 1) statistically significant

222 differences were observed between the gingivitis and periodontitis groups $(\mathrm{p}=0.0090)$ and the

223 normal and periodontitis groups $(\mathrm{p}=0.0043)$. However, no statistical difference was observed

224 between the normal and gingivitis groups $(\mathrm{p}=0.181)$.

225 For known bacteria identified by culture-independent methods (Table 2) statistically 226 significant differences were observed between all three groups $(\mathrm{p}<0.000001)$.

227 For potentially novel bacteria identified by culture-independent methods (Table 3), 228 statistically significant differences were observed between all three groups $(\mathrm{p}<0.00020)$.

\section{Discussion}

Canine periodontal disease is one of the most common infectious diseases of companion animals and is characterised by gingival inflammation and tooth loss (Hennet \& Harvey, 1992;

234 Harvey, 1998). Black pigmenting anaerobic bacteria, in particular Porphyromonas and Prevotella 235 species, have been isolated from the periodontal pockets of dogs with periodontal disease 236 (Watson, 1994; Gorrel and Rawlings, 1996). Isogai et al. (1999) isolated several pigmented 237 Porphyromonas species from cases of canine periodontal disease. Several new Porphyromonas 238 species (Porphyromonas cangingivalis, Porphyromonas cansulci, Porphyromonas gulae, 239 Porphyromonas creviocanis, Porphyromonas gingivacanis, Porphyromonas canoris, 
240 Porphyromonas denticanis) associated with the disease have also been described (Collins et al.,

241 1994; Hirasawa and Takada, 1994; Love et al., 1994; Fournier et al., 2001; Hardham et al., 2005).

242 Our current study is the first to use molecular cloning and sequencing of bacterial 16S rRNA

243 genes, in addition to conventional microbiological culture methods, to identify the bacteria

244 associated with canine gingivitis, periodontitis and oral health. Given the relatively small number

245 of samples analysed, it was not possible to age- and sex- match the animals used in the study,

246 although this would be desirable in future large-scale studies. Despite the relatively small number

247 of samples analysed in each group in our current study, clear correlations were seen to emerge

248 between disease status and the prevalence of specific bacterial species, and differences in the

249 microflora between the three groups was statistically significant. The most prevalent species

250 found in the normal, gingivitis and periodontitis groups were Pseudomonas sp. (30.9\%),

251 Porphyromonas cangingivalis (16.1\%) and Desulfomicrobium orale (12.0\%), respectively.

252 Porphyromonas cangingivalis was first isolated from cases of canine periodontitis (Collins et al.,

253 1994) and Desulfomicrobium orale has been isolated from cases of human periodontitis

254 (Langendijk et al., 2001). Other prevalent species identified included Porphyromonas canoris,

255 Tannerella forsythensis and Capnocytophaga cynodegmi (gingivitis), and Actinomyces sp. and

256 Capnocytophaga cynodegmi (periodontitis). The association of Tannerella forsythensis with

257 human periodontal disease is well documented, Capnocytophaga cynodegmi is found in the oral

258 cavity of the vast majority of dogs (van Dam et al., 2009) and Porphyromonas canoris has been

259 isolated from canine dental plaque samples (Allaker et al., 1997). Culture-independent methods

260 showed that microbial diversity was similar in all three groups (19 to 24 phylotypes). Uncultured

261 bacteria were found at a higher proportion in the normal samples $(13.2 \%)$ compared to the

262 gingivitis $(2.0 \%)$ and periodontitis (10.5\%) samples. Potentially novel species were found at high

263 proportions in all three groups (35.3\% to $38.3 \%$ ), a finding that is unsurprising when one 
264 considers that this is the first study to use culture-independent methods to identify bacteria in the

265 canine oral cavity. However, sequencing of the entire 16S rRNA gene would be required to 266 confirm these species as being novel.

267 The finding that Pseudomonas sp., Porphyromonas cangingivalis and Desulfomicrobium 268 orale were the predominant species identified by culture-independent methods in the normal, 269 gingivitis and periodontitis samples, respectively, is not corroborated by the culture data

270 obtained. However, some concordance does exist between the data since some species were 271 detected by both identification methods (three, nine and five species in the normal, gingivitis and 272 periodontitis samples, respectively). In addition, previously uncultured bacteria were identified 273 by both methods in all three groups. However, many bacteria were identified by culture274 independent methods but not by culture methods. A possible explanation for this anomaly is the 275 use of standard culture media and incubation conditions, which were adopted to ensure that as 276 many different types of bacteria as possible were cultured. However, this approach may not have 277 been suitable for the culture of many species, particularly those with fastidious growth 278 requirements. Consequently, we advocate that culture-independent methods should be used in 279 conjunction with conventional culture methods in order to identify the total microflora in clinical 280 samples. Conversely, some bacteria isolated by culture methods were not identified by culture281 independent methods. The most likely explanation for this additional anomaly is PCR primer 282 bias, which is caused by self-annealing of the most abundant templates in the late stages of 283 amplification (Suzuki and Giovannoni, 1996) or as a result of differences in the amplification 284 efficiency of different templates (Polz and Cavanaugh, 1998). This results in the differential 285 amplification of PCR products, leading to an inaccurate reflection of the true numbers of species 286 present within the sample. 
In conclusion, a wide range of bacteria is present in the oral cavity of healthy dogs and those with gingivitis and periodontitis and a distinct microbial flora appears to be associated with each of the three groups. Potentially novel bacterial species may play a significant role in gingivitis 290 and periodontitis.

291

\section{Conflict of interest statement}

The authors have no conflicts of interest.

\section{Acknowledgements}

We thank the Royal College of Veterinary Surgeons Trust for their financial support and Dr

299 David Lappin for carrying out the statistical analysis.

\section{References}

Allaker, R.P., de Rosayro, R., Young, K.A., Hardie, J.M., 1997. Prevalence of Porphyromonas and Prevotella species in the dental plaque of dogs. Veterinary Record 140, 147-148.

Altschul, S.F., Madden, T.L., Schäffer, A.A., Zhang, J., Zhang, Z., Miller, W., Lipman, D.J., 1997. Gapped BLAST and PSI-BLAST: a new generation of protein database search programs. Nucleic Acids Research 25, 3389-3402.

Boyce, E.N., Ching, R.J.W., Logan, E.I., Hunt, J.H., Maseman, D.C., Gaeddert, K.L., King, C.T., Reid, E.E., Hefferren, J.J., 1995. Occurrence of gram-negative black-pigmented anaerobes in 

subgingival plaque during the development of canine periodontal disease. Clinical Infectious

$311 \quad$ Diseases 20 (Suppl 2), S317-S319.

312 Clarridge, J.E. III, 2004. Impact of 16S rRNA gene sequence analysis for identification of 313 bacteria on clinical microbiology and infectious diseases. Clinical Microbiology Reviews 17, $314 \quad 840-862$.

315 Collins, M.D., Love, D.N., Karjalainen, J., Kanervo, A., Forsblom, B., Willems, A., Stubbs, S., 316 Sarkiala, E., Bailey, G.D., Wigney, D.I., Jousimies-Somer, H., 1994. Phylogenetic analysis of 317 members of the genus Porphyromonas and description of Porphyromonas cangingivalis sp. 318 nov. and Porphyromonas cansulci sp. nov. International Journal of Systematic Bacteriology $319 \quad 44,674-679$.

320 Fournier, D., Mouton, C., Lapierre, P., Kato, T., Okuda, K., Ménard, C., 2001. Porphyromonas 321 gulae sp. nov., an anaerobic, Gram-negative coccobacillus from the gingival sulcus of various animal hosts. International Journal of Systematic and Evolutionary Microbiology 51, 11791189.

324 Golden, A.L., Stoller, N., Harvey, C.E., 1982. A survey of oral and dental diseases in dogs 325 anesthesized at a veterinary hospital. Journal of the American Animal Hospital Association $326 \quad 18,891-899$.

327 Gorrel, C., Rawlings, J.M., 1996. The role of a 'dental hygiene chew' in maintaining periodontal health in dogs. Journal of Veterinary Dentistry 13(1), 31-34.

329 Hardham, J., Dreier, K., Wong, J., Sfintescu, C., Evans, R.T., 2005. Pigmented-anaerobic bacteria associated with canine periodontitis. Veterinary Microbiology 106, 119-128.

331 Harvey, C. E., Emily, P.P., 1993. Periodontal disease. In: Harvey, C.E., Emily, P.P. (Eds.), Small 332 Animal Dentistry. Mosby, St. Louis, USA, pp. 89-144. 
333 Harvey, C.E., 1998. Periodontal disease in dogs. Etiopathogenesis, prevalence, and significance.

$334 \quad$ Veterinary Clinics of North America: Small Animal Practice 28, 1111-1128.

335 Hennet, P.R., Harvey, C.E., 1991a. Anaerobes in periodontal disease in the dog: a review.

336 Journal of Veterinary Dentistry 8(2), 18-21.

337 Hennet, P.R., Harvey, C.E., 1991b. Spirochetes in periodontal disease in the dog: a review.

338 Journal of Veterinary Dentistry 8(3), 16-17.

339 Hennet, P.R., Harvey, C.E., 1992. Natural development of periodontal disease in the dog: a

340 review of clinical, anatomical and histological features. Journal of Veterinary Dentistry 9(3),

$341 \quad 13-19$.

342 Hirasawa, M., Takada, K., 1994. Porphyromonas gingivicanis sp. nov. and Porphyromonas

343 crevioricanis sp. nov., isolated from beagles. International Journal of Systematic Bacteriology $344 \quad 44,637-640$.

345 Isogai, H., Kosako, Y., Benno, Y., Isogai, E., 1999. Ecology of genus Porphyromonas in canine 346 periodontal disease. Journal of Veterinary Medicine. Series B 46, 467-473.

347 Langendijk, P.S., Kulik, E.M., Sandmeier, H., Meyer, J., van der Hoeven, J.S., 2001. Isolation of

348 Desulfomicrobium orale sp. nov. and Desulfovibrio strain NY682, oral sulfate-reducing 349 bacteria involved in human periodontal disease. International Journal of Systematic and $350 \quad$ Evolutionary Microbiology 51, 1035-1044.

351 Lindhe, J., Hamp, S.-E., Löe, H., 1973. Experimental periodontitis in the Beagle dog. Journal of 352 Periodontal Research 8, 1-10.

353 Love, D.N., Karjalainen, J., Kanervo, A., Forsblom, B., Sarkiala, E., Bailey, G.D., Wigney, D.I., 354 Jousimies-Somer, H., 1994. Porphyromonas canoris sp. nov., an asaccharolytic, black355 pigmented species from the gingival sulcus of dogs. International Journal of Systematic $356 \quad$ Bacteriology 44, 204-208. 
Marchesi, J.R., Sato, T., Weightman, A.J., Martin, T.A., Fry, J.C., Hiom, S.J., Wade, W.G., 1998.

358 Design and evaluation of useful bacterium-specific PCR primers that amplify genes coding 359 for bacterial 16S rRNA. Applied and Environmental Microbiology 64, 795-799.

360 Polz, M.F., Cavanaugh, C.M., 1998. Bias in template-to-product ratios in multitemplate PCR. 361 Applied and Environmental Microbiology 64, 3724-3730.

362 Riggio, M.P., Lennon, A., Wray, D., 2000. Detection of Helicobacter pylori DNA in recurrent 363 aphthous stomatitis tissue by PCR. Journal of Oral Pathology and Medicine 29, 507-513.

364 Spratt, D.A., 2004. Significance of bacterial identification by molecular biology methods. 365 Endodontic Topics 9, 5-14.

366 Suzuki, M.T., Giovannoni S.J., 1996. Bias caused by template annealing in the amplification of

van Dam, A.P., van Weert, A., Harmanus, C., Hovius, K.E, Claas, E.C.J., Reubsaet, F.A.G., mixtures of 16S rRNA genes by PCR. Applied and Environmental Microbiology 62, $625-630$.

373 Watson, A.D.J., 1994. Diet and periodontal disease in dogs and cats. Australian Veterinary $374 \quad$ Journal 71, 313-318. 
Table 1 Bacterial species identified by 16S rRNA gene sequencing of isolates obtained from

381 three normal, three gingivitis and three periodontitis samples (all at least $98 \%$ identity).

\begin{tabular}{|c|c|c|c|}
\hline \multirow{2}{*}{ Species } & Normal & Gingivitis & Periodontitis \\
\hline & $\begin{array}{c}\text { No. of isolates } \\
\text { (\% of total) } \\
n=32\end{array}$ & $\begin{array}{c}\text { No. of isolates } \\
\text { (\% of total) } \\
n=30\end{array}$ & $\begin{array}{c}\text { No. of isolates } \\
\text { (\% of total) } \\
n=36\end{array}$ \\
\hline Actinomyces bowdenii & $1(3.1)$ & & (e) \\
\hline Actinomyces canis & $1(3.1)$ & & $7(19.4)$ \\
\hline Actinomyces coleocanis & & $1(3.3)$ & \\
\hline Actinomyces hordeovulneris & $1(3.1)$ & 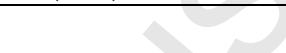 & $2(5.6)$ \\
\hline Bacteroides heparinolyticus & & $3(10.0)$ & \\
\hline Bergeyella sp. & & $1(3.3)$ & \\
\hline Brachybacterium zhongshanense & & $1(3.3)$ & \\
\hline Brevundimonas sp. & $1(3.1)$ & +2 & \\
\hline Buttiaxella agrestis & $2(6.3)$ & $\overline{0}$ & \\
\hline Capnocytophaga canimorsus & & $1(3.3)$ & \\
\hline Capnocytophaga cynodegmi & & & $3(8.3)$ \\
\hline $\begin{array}{l}\text { Capnocytophaga cynodegmi / } \\
\text { canimorsus* }\end{array}$ & & & $2(5.6)$ \\
\hline Corynebacterium lipophiloflavum & & $1(3.3)$ & \\
\hline Corynebacterium sp. & 00 & $1(3.3)$ & $2(5.6)$ \\
\hline Cytophaga sp. & 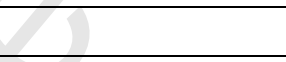 & & $2(5.6)$ \\
\hline Filifactor vilosus & 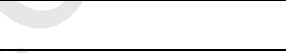 & $1(3.3)$ & $1(2.8)$ \\
\hline Fusobacterium alosis & - & & $1(2.8)$ \\
\hline Fusobacterium canifelinum & $1(3.1)$ & & \\
\hline Fusobacterium russii & & $1(3.3)$ & \\
\hline Gemella palaticanis & $1(3.1)$ & & \\
\hline Lactobacillus casei / lactis* & $1(3.1)$ & & \\
\hline $\begin{array}{l}\text { Leucobacter chromireducens / } \\
\text { solipictus* }\end{array}$ & $1(3.1)$ & & \\
\hline Moraxella bovoculi & & & $2(5.6)$ \\
\hline Moraxella canis & & $1(3.3)$ & \\
\hline Moraxella sp. & $1(3.1)$ & & \\
\hline Neisseria canis & & $2(6.7)$ & $2(5.6)$ \\
\hline Neisseria weaveri & $3(9.4)$ & $1(3.3)$ & $1(2.8)$ \\
\hline Neisseria zoodegmatis & $1(3.1)$ & & \\
\hline Pasteurella canis & & $1(3.3)$ & $1(2.8)$ \\
\hline Pasteurella dagmatis & $1(3.1)$ & $3(10.0)$ & $1(2.8)$ \\
\hline Pasteurella multocida subsp. septica & $1(3.1)$ & & \\
\hline $\begin{array}{l}\text { Pasteurella multocida subsp. septica } \\
\text { / multocida* }\end{array}$ & $2(6.3)$ & & \\
\hline
\end{tabular}




\begin{tabular}{|l|l|l|l|}
\hline Pasteurella stomatis & $1(3.1)$ & & \\
\hline Pasteurella trehalosi & $1(3.1)$ & & \\
\hline Porphyromonas canoris & $1(3.1)$ & $2(6.7)$ & \\
\hline Propionibacteriaceae bacterium ${ }^{1}$ & & $1(3.3)$ & \\
\hline Pseudoclavibacter sp. & & $2(6.7)$ & \\
\hline Pseudomonas aeruginosa & $1(3.1)$ & & \\
\hline Pseudomonas brenneri & & & $2(5.6)$ \\
\hline Pseudomonas sp. & & & $3(8.3)$ \\
\hline Pseudomonas stutzeri & $1(3.1)$ & & \\
\hline Serratia grimesii & $1(3.1)$ & & \\
\hline Serratia sp. & $1(3.1)$ & & \\
\hline Streptococcus minor & $1(3.1)$ & & \\
\hline Uncultured bacterium $^{\text {Uncultured Bacteroidetes bacterium }}{ }^{2}$ & $4(12.5)$ & $2(6.7)$ & $3(8.3)$ \\
\hline Virgibacillus halophilus $^{1}$ & $1(3.1)$ & & $1(2.8)$ \\
\hline Xanthomonadaceae bacterium & & & \\
\hline Xanthomonas sp. & & $2(6.7)$ & \\
\hline Xenophilus sp. & & $1(3.3)$ & \\
\hline
\end{tabular}

$384 *$ Unable to distinguish between species: ${ }^{1}$ Family; ${ }^{2}$ Phylum. 
397 Table 2 Bacterial species identified by $16 \mathrm{~S}$ rRNA sequencing of clones from three normal, three

398 gingivitis and three periodontitis samples: at least $98 \%$ identity.

\begin{tabular}{|c|c|c|c|}
\hline \multirow[b]{2}{*}{ Species } & Normal & Gingivitis & Periodontitis \\
\hline & $\begin{array}{c}\text { No. of clones } \\
\text { analysed } \\
\text { (\% of total) } \\
n=152 \\
\end{array}$ & $\begin{array}{c}\text { No. of clones } \\
\text { analysed } \\
\text { (\% of total) } \\
n=149 \\
\end{array}$ & $\begin{array}{c}\text { No. of clones } \\
\text { analysed } \\
(\% \text { of total) } \\
n=133\end{array}$ \\
\hline Acinetobacter junii & & & $1(0.8)$ \\
\hline Acinetobacter sp. & $1(0.7)$ & a & 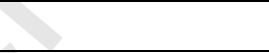 \\
\hline Actinomyces hordeovulneris & & $1(0.7)$ & \\
\hline Actinomyces sp. & $1(0.7)$ & $1(0.7)$ & $11(8.3)$ \\
\hline Bergeyella sp. & $5(3.3)$ & $6(4.0)$ & \\
\hline Capnocytophaga canimorsus & & $1(0.7)$ & $2(1.5)$ \\
\hline Capnocytophaga cynodegmi & & $6(4.0)$ & $10(7.5)$ \\
\hline CDC Group NO-1 & & $1(0.7)$ & \\
\hline Clostridiales bacterium (oral) $^{3}$ & & 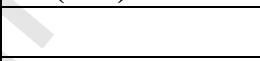 & $6(4.5)$ \\
\hline Clostridium sporogenes / botulinum* & $1(0.7)$ & & \\
\hline Desulfomicrobium orale & & & $16(12.0)$ \\
\hline Filifactor villosus & 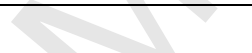 & $4(2.7)$ & \\
\hline Fusobacterium russii & + & $2(1.3)$ & \\
\hline Gemella palaticanis & $1(0.7)$ & & \\
\hline Klebsiella pneumoniae & $1(0.7)$ & & \\
\hline Methylobacterium radiotolerans & $1(0.7)$ & & \\
\hline Moraxella bovoculi & & $3(2.0)$ & $3(2.3)$ \\
\hline Moraxella canis & & & $1(0.8)$ \\
\hline Moraxella nonliquefaciens & $1(0.7)$ & & \\
\hline Neisseria canis & & $1(0.7)$ & \\
\hline Orodibacter denticanis & & $2(1.3)$ & \\
\hline Pasteurella canis & & $5(3.4)$ & $4(3.0)$ \\
\hline Pasteurella dagmatis & & & $5(3.8)$ \\
\hline Peptococcus sp. (oral) & & $3(2.0)$ & \\
\hline Peptoniphilus sp. 'Oral Taxon 386' & & & $2(1.5)$ \\
\hline Peptostreptococcus sp. (oral) & & & $5(3.8)$ \\
\hline Porphyromonas cangingivalis & & $24(16.1)$ & $2(1.5)$ \\
\hline Porphyromonas canis & & $1(0.7)$ & \\
\hline Porphyromonas canoris & & $8(5.4)$ & $1(0.8)$ \\
\hline Pseudomonas sp. & $47(30.9)$ & & \\
\hline Psychrobacter pulmonis & $2(1.3)$ & & \\
\hline Salibacillus sp. & $1(0.7)$ & & \\
\hline Serratia grimesii & $3(2.0)$ & & \\
\hline Serratia proteomaculans & $2(1.3)$ & & \\
\hline Serratia proteomaculans quinovora & $1(0.7)$ & & \\
\hline Simonsiella steedae & $2(1.3)$ & & \\
\hline
\end{tabular}




\begin{tabular}{|l|l|l|l|}
\hline Tannerella forsythensis & & $7(4.7)$ & \\
\hline Treponema genomosp. & & $2(1.3)$ & \\
\hline Treponema sp. & & $4(2.7)$ & $1(0.8)$ \\
\hline Uncultured Acinetobacter sp. & $5(3.3)$ & & \\
\hline Uncultured bacterium & $12(7.9)$ & $1(0.7)$ & $7(5.3)$ \\
\hline Uncultured Capnocytophaga sp. & & & $1(0.8)$ \\
\hline $\begin{array}{l}\text { Uncultured Peptostreptococcaceae } \\
\text { bacterium }\end{array}$ & & & $4(3.0)$ \\
\hline Uncultured Prevotellaceae bacterium & & & \\
\hline Uncultured Pseudomonas sp. & $3(2.0)$ & $2(1.3)$ & \\
\hline Uncultured rumen bacterium & & & $2(1.5)$ \\
\hline Virgibacillus halophilus & $4(2.6)$ & & \\
\hline Wernerella denticanis & & $1(0.7)$ & \\
\hline Xanthomonadaceae bacterium & & $3(2.0)$ & $2(1.5)$ \\
\hline Xenophilus sp. & & $3(2.0)$ & \\
\hline
\end{tabular}

400 *Unable to distinguish between species; ${ }^{1}$ Family; ${ }^{3}$ Order.

401

402

403

404

405

406

407

408

409

410

411

412

413

414

415

416 
Table 3 Potentially novel bacterial species identified by $16 \mathrm{~S}$ rRNA sequencing of clones from

418 three normal, three gingivitis and three periodontitis samples: less than $98 \%$ identity.

\begin{tabular}{|c|c|c|c|}
\hline \multirow{2}{*}{ Species [\% identity range] } & Normal & Gingivitis & Periodontitis \\
\hline & $\begin{array}{l}\text { No. of clones } \\
\text { analysed } \\
\text { (\% of total) } \\
n=152\end{array}$ & $\begin{array}{c}\text { No. of clones } \\
\text { analysed } \\
\text { (\% of total) } \\
n=149\end{array}$ & $\begin{array}{c}\text { No. of clones } \\
\text { analysed } \\
\text { (\% of total) } \\
n=133\end{array}$ \\
\hline Actinomyces sp. [95.5-97.4] & $1(0.7)$ & 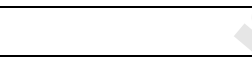 & $2(1.5)$ \\
\hline Actinomyces hordeovulneris [96.9] & $1(0.7)$ & 8 & $\Delta$ \\
\hline Arthrobacter sp. [93.8] & $2(1.3)$ & & \\
\hline Bacteroides sp. [89.9] & & & $2(1.5)$ \\
\hline Brachymonas sp. [96.9] & & $2(1.3)$ & \\
\hline Capnocytophaga canimorsus [96.7-97.0] & & $3(2.0)$ & \\
\hline Capnocytophaga cynodegmi [97.1] & & 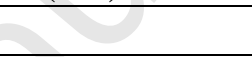 & $1(0.8)$ \\
\hline Clostridiales bacterium (oral) ${ }^{3}$ [85.4-97.2] & (N) & $13(8.7)$ & $6(4.5)$ \\
\hline Corynebacterium pseudotuberculosis [94.6] & & $1(0.7)$ & \\
\hline Desulfomicrobium orale [96.2-97.2] & & 7 & $3(2.3)$ \\
\hline Desulfovibrio sp. [89.9] & trat & & $1(0.8)$ \\
\hline Flexistipe-like sp. (oral) [95.7] & + & $1(0.7)$ & \\
\hline Haemophilus haemoglobinophilus [96.2] & $1(0.7)$ & & \\
\hline Klebsiella sp. [97.1] & $1(0.7)$ & & \\
\hline Marine bacterium [96.6] & $1(0.7)$ & & \\
\hline Moraxella bovoculi [96.2] & Pre & & $1(0.8)$ \\
\hline Moraxella canis [97.1] & & & $1(0.8)$ \\
\hline Mycobacterium sp. [95.7] & $1(0.7)$ & & \\
\hline Mycoplasma canis [91.5] & & $1(0.7)$ & \\
\hline Pasteurella sp. [97.2] & & & $1(0.8)$ \\
\hline Porphyromonas cangingivalis [85.5-97.4] & & $4(2.7)$ & $1(0.8)$ \\
\hline Porphyromonas canoris [95.6-97.1] & & $2(1.3)$ & $2(1.5)$ \\
\hline Prevotella genomosp. P9 (oral) [90.2] & & & $2(1.5)$ \\
\hline Pseudomonas fluorescens [93.2] & $1(0.7)$ & & \\
\hline Pseudomonas sp. [96.4-97.3] & $20(13.2)$ & & \\
\hline Psychrobacter pulmonis [94.7] & $1(0.7)$ & & \\
\hline Salibacillus sp. [96.2-96.9] & $2(1.3)$ & & \\
\hline Serratia proteomaculans quinovora [97.2] & $1(0.7)$ & & \\
\hline Simonsiella steedae [92.3-97.1] & $2(1.3)$ & & \\
\hline Tannerella forsythensis [97.3] & & $1(0.7)$ & \\
\hline Uncultured bacterium [87.7-96.8] & $5(3.3)$ & $16(10.7)$ & $18(13.5)$ \\
\hline Uncultured beta-proteobacterium [94.0] & $2(1.3)$ & & \\
\hline Uncultured Lachnospiraceae (oral) ${ }^{1}[94.6]$ & & $1(0.7)$ & \\
\hline Uncultured Lautropia sp. (oral) [97.2-97.4] & & $5(3.4)$ & \\
\hline $\begin{array}{l}\text { Uncultured Moraxellaceae bacterium } \\
\text { (oral) }{ }^{1}[96.4]\end{array}$ & & & $1(0.8)$ \\
\hline
\end{tabular}




\begin{tabular}{|l|l|l|l|}
\hline Uncultured Peptococcus sp. (oral) [96.9] & & $1(0.7)$ & \\
\hline $\begin{array}{l}\text { Uncultured Porphyromonas sp. (oral) } \\
\text { [93.2-93.6] }\end{array}$ & & & $3(2.3)$ \\
\hline Uncultured Prevotella sp. (oral) [80.6] & & & $1(0.8)$ \\
\hline Uncultured rumen bacterium [88.5] & & & $1(0.8)$ \\
\hline Uncultured $\gamma$-proteobacterium [94.1] & & $1(0.7)$ & \\
\hline Virgibacillus marismortui [95.7-97.0] & $13(8.6)$ & & \\
\hline Virgibacillus sp. [96.0] & $3(2.0)$ & & \\
\hline Xanthomonadaceae bacterium1 [96.0-96.8] & & $5(3.4)$ & \\
\hline
\end{tabular}

419

$420 \quad{ }^{1}$ Family; ${ }^{3}$ Order.

421

422

The $\%$ identity range indicates the $\%$ identities of analysed clones from each phylotype with best

423

424 matching sequences in the database. 